\title{
リチウム,バリウムおよびストロンチウム をふくむマンガン合金
}

$$
\begin{array}{llllll}
\text { 大日方 } & \text { - 司** } & \text { 竹 内 } & \text { 庸** } \\
\text { 栗 原 健 } & \text { 助** } & \text { 渡 辺 } \text { 正 晴** }
\end{array}
$$

Ichiii Obinata, Yo Takeuchi, Kensuke Kurihara und Masaharu Watanabe: Uber die Legierungen des Mangans und Siliziums mit Alkali-und Erdalkalimetallen. I. Legierungen des Mangans mit Lithium, Barium und Strontium. Bekanntlich uben die Zusatze von Alkal1-und Erdalkalimetallen zu E1senschmelzen vor allem zur Veredelung des Gußeisens durch Kugelgraphitstruktur eine beachtliche Wirkung aus. Auch wegen threr starken Affinitat fur Gase in der Schmelze hieraus folgt eine interessante Möglıckeit der Eigenschaftsverbesserung fur Stahle sowie Kupferlegierungen. 'Dies wirft die Frage auf, wie diese Metalle zur Eisenschmelze wirksam zugesetzt werden kann. Zu diesem $Z$ weck könnte man vorschlagen, diese Metalle in Form einer Leg1erung mit Mangan sowie Silizıum $z \mathfrak{u}$ verwenden. Das System Mangan-Kalzium ist kurzlich von den Verfassern (1) ausgearbeitet worden. Auf Grund der Erfahrungen wurden die Systeme Mangan-Lithium, Mangan-Barium und Mangan-Strontium untersucht und die Zustandsbider als Entwurf aufgestellt. In diesen drei Systemen ist keine intermetallische Verbindung als dritte

** 東北大学金属材料研究所 (The Rescarch Institute for Iron, Steel and Other Metals, Tohoku University, Sendai)
* 1963 年 10 月本会名古屋大会および 1964 年 4 月本 会東京大会溌表; アルカリ接よびアルカリ土類金 属を含むマンガソおよび硅素合金の研究 (第1 報) 
Phase vorhanden. Die Bestandteile dieser Legierungen sind im flüßigen Zustand nur teilweise mischbar und bilden in einem breiten Konzentrationsbereich eine Mischungslücke. Die Mischungslücken dehnen sich auf das Intervall von 0.15 bis $97.0 \%$ Li bei $1253^{\circ} \mathrm{C}$ im System ManganLithium, von 0.62 bis $97.3 \%$ Ba bei $1250^{\circ} \mathrm{C}$ im System Mangan-Barium und von 1.18 bis $97.8 \%$ Sr bei $1240^{\circ} \mathrm{C}$ im System Mangan-Strontium aus.

(Eingegangen am 23, April, 1964)

\section{I. $え$ かi き}

フルカリ抽びアルカリ土類金属の添加によつて，鋳鉄 の黒鉛組織が改良されるとい5ことは，従来よく知られて いる.またこの種の金属は他の金属溶湯中のガスとよく 結合するところから，たと辛，鋼や銅合金の性質を向上 させるのに役立つだろらと期待される。しかしこれらの 金属をどのようにして添加するかということが，まつ䦗題 となるたるろっ。この目的のためには，颃そらく，マンガン ないしは硅素との合金の形で利用するのが有効であるうと 考光られる。

マンガンーカルシウム系合金(1)については，さきに著者 らによつて行なわれた研究がある、リチウム，バリウムお よびストロンチウムをふくむマンガン合金については，今 日まで何知られていない，通常の熔解法によつては，純 粋な合金をつくることができなかつたためである。しか し，この困難な点る，マンガンーカルシウム合金(1)の場合 と同様に，アルゴン雾围気下のフーク熔解法によつてほぼ 解決された。
るつ厌とと斗に，鋼製容器の中に密封し，外気には全く触 れない状態で $1300^{\circ} \mathrm{CK} 15$ 分閒加熱した.生成物の観察か ら,この種の方法では純粋な合金は得られないことが明ら かとなつた、なぜなら，いずれの金属も，熔融状熊に括い ては，るつば材とはげしく反応を执こし，そのため大量の 鉱涬をつくつてしま 3 からである、その上, 鋼媻容器自身 すらかなり著しく侵されることがわからた。

前に述べたように，この難点はアルゴン雲囲気下のア一 ク熔解の適用によつて解決された。この方法は、ンガンー カルシウム合金(1)の熔製のさいにはじめて試みられたが， リチウム，バリウムおよびストロンチウムをふくをてンガ

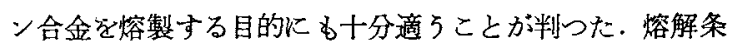
件はつぎの通りである，電流の強さ $100 \sim 200 \mathrm{~A}$ ，電圷䄪 $20 \mathrm{~V}$, 熔解時間約 5 分, 熔解量 $5 \sim 20 \mathrm{~g}$.な持,この方法で は水冷式銅るつぼの中で熔解されるので，単に一度かぎり の熔解で均質な合金を得ることはむずかしい，そのため， 数回の反転熔解を行なつた，Tabelle 1 は組成の異なつた いくつかの合金の熔解損失を示したものである.表から明 らがこれらの金属成分，とくにリチウム技よびストロ

Tabelle 1 Schmelzverlust beim Lichtbogenschmelzen von einigen untersuchten Legierungen des Mangans mit Barium, Strontium und Lithium.

\begin{tabular}{|c|c|c|c|c|c|c|}
\hline \multicolumn{4}{|c|}{$\begin{array}{l}\text { Zusammensetzung der Legierungen } \\
\text { in Gew. }-\% \%\end{array}$} & \multirow{2}{*}{$\begin{array}{l}\text { Einsatzmenge } \\
\text { in } \mathrm{gr} .\end{array}$} & \multirow{2}{*}{$\begin{array}{l}\text { Gewicht der } \\
\text { Knopfproben } \\
\text { in } \mathrm{gr} .\end{array}$} & \multirow{2}{*}{$\begin{array}{c}\text { Schmelzverlust } \\
\text { in } \%\end{array}$} \\
\hline Mangan & Barium & Strontium & Lithium & & & \\
\hline $\begin{array}{l}20 \\
50 \\
90 \\
50 \\
70 \\
20 \\
50 \\
90\end{array}$ & $\begin{array}{l}80 \\
50 \\
10\end{array}$ & $\begin{array}{l}50 \\
30\end{array}$ & $\begin{array}{l}80 \\
50 \\
10\end{array}$ & $\begin{array}{r}10 \\
20 \\
20 \\
6 \\
10 \\
5 \\
6 \\
10\end{array}$ & $\begin{array}{c}9.9 \\
19.9 \\
19.95 \\
5.9 \\
9.8 \\
4.95 \\
5.95 \\
9.85\end{array}$ & $\begin{array}{l}1.0 \\
0.5 \\
0.3 \\
1.7 \\
2.0 \\
1.0 \\
0.8 \\
1.5\end{array}$ \\
\hline
\end{tabular}

こうして得られたいわゆるボタン試料の組織観察と化学 分析，熱分析の結果にもとずいて，マンガンーリチウム， マンガンーハリウム拈よびマンガンーストロンチウム各二元 系の平衡関係を明らかにしたので，ここに報告する。

\section{II. 实殹 方 法}

合金の熔製に用いられた金属地金の純度はつぎの通りで ある. $99.9 \% \% \mathrm{Mn}, 99.9 \% \mathrm{Li}, 99.9 \% \mathrm{Ba}$ 扣よび $99.0 \% \mathrm{Sr}$.

最初ベリリヤとかアルミナのるつぼを用いて，合金を 熔製する試みを行なつた，この場合，所定量の装入物を，

(1) I. Obinata, K. Kurihara, Y. Takeuchi and M. Watanabe: Metall, 17 (1963)，1205 㧊よび本誌, 27 (1963) , 251.
ンチウムは高温で高い蒸気压をるつにすかかからず, アー ク熔解のさいの損失は予想以上に少ない。したが放 み通りの組成をるつ合金をつくることは容易であつた。

こうして得られたボタン試料を切断した後，組織観察に 供した、バリウム拉よびストロンチウムをふくを合金の研 摩は酸化ク口ムの粉末と雉水アルコールを用いて行なえば うまくいく、一方，リチウムをふくむ合金の皆合には，こ の種の研摩剂を用いても効果はないので，よく乾いた上質 の布で注意樑く磿くしかない。

後述するように，リチウム，バリウム拈よびストロンチ ウムをふくむマンガン合金は，骶液に和いて二济相に分䧿 する.この両者の凝固後の組成を化学分析によつて決定し た，マンガン富相中のりチウム，ハリウム柆びストロン 
チウムを分析する場合には，まづ，ボタン試料中のマンガ ン富相を蒸溜水に浸漬して表面に付着しているリチウム， バリウムおよびストロンチウムを除去した後, 溶けずに残 つたマンガン相を分析した。一方, 同じボタン試料からり チウム，バリウム括よびストロンチウム富相を注意深く切 り出しそそれぞれの相にふくまれているマンガン量を分析 した.

これらの合金の熱分析用るつぼとして，本研究において はタングステンるつばを用いた・タングステンがマン ガン融液によつて侵されないといらことは，D，Kremer(2) やU.Zwicker(3)によつて確められている.このタングス テンるつばは焼結ブロックを放電加工によつてくり抜い てつくつたbのである， $\mathbf{A b b} 1$ は用いたタングステン るつ代とそれを保護するための鋼製密閉容器の略図であ

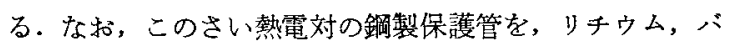

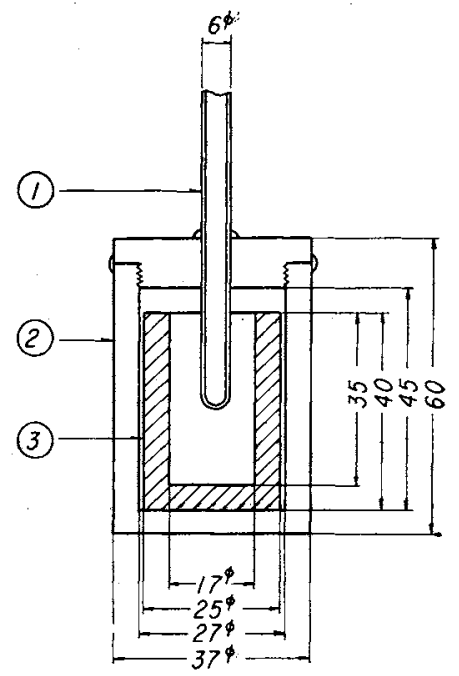

Abb.1 Skizze des Stahlbehälters mit Wolframtiegel für die thermische Analyse der Manganlegierungen mit Barium, Strontium und Lithium. (Einheit; $\mathrm{mm}$ )

1. Schutzrohr für das thermoelement

2. Stahlbehälter

3. Wolframtiegel

リウムおよびストロンチウム富融液とのみ接触し，マンガ ン富融液とは接しないように配置した。.F.Wever(4)，N. V,Ageev 怙よび M.I.Zamotorin(5)らによれば，鋼はりチ ウム，バリウムおよびストロンチウムの各融液に詨して 快，事実上安定だからである，もろん，この方法だとマン ガン融液の凝固熱は問接的に捉方られることになるが，凝 固過程を追求する上では何らの支障る机こらなからた。こ

(2) D. Kremer : Abhandl. Inst. Metallhütt. u. Elektromet. Tech., Hochsch., Aachen, 1 (1916) , 1.

(3) U.Zwicker: Z.Metallkunde, 42(1951), 251.

(4) F.Wever: Arch:Eisenhütt., $2(1928-29), 739$.

(5) N. V. Ageev, and M. I. Zamotorin : Izvest. Leningrad. Politech, Inst., Otde1. Mat. Fiz Nauk, $31(1928), 183$;
の場合の温度变化を自動平衡式 $\mathrm{X}$ - $\mathrm{Y}$ 記録計によつて測定 した.

マンガンと他の成分間の溶解度をもとめるために，ボタ ン試料をいろいらな温度に加熱した， $1000^{\circ} \mathrm{C}$ 以下の爇処 理のさいは，熱分析の昜合と同様，ボタン試料をタングス テンるつばの中に入れて加熱したが， $1000^{\circ} \mathrm{C}$ 以下の場合 には、タングステンるつばは用いず，単に鋼製密閉容器の みを用いた， $1000^{\circ} \mathrm{C}$ 以下では，銅と合金との反応はきわ めてゆつくりと進むので，鉄による合金の污染は，問題に するほど著しくないからである。

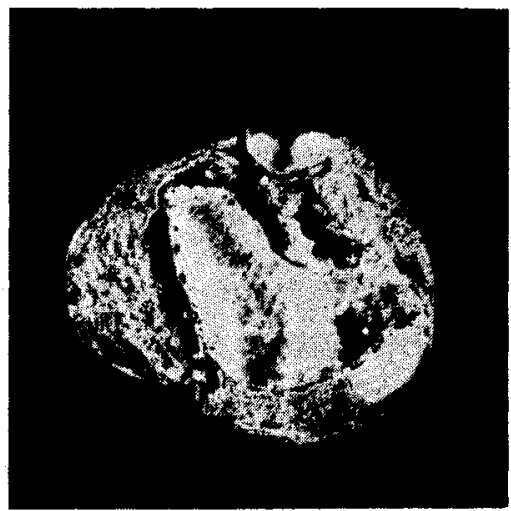

(a) $90 \% \mathrm{Mn}-10 \% \mathrm{Li}-$ Legierung

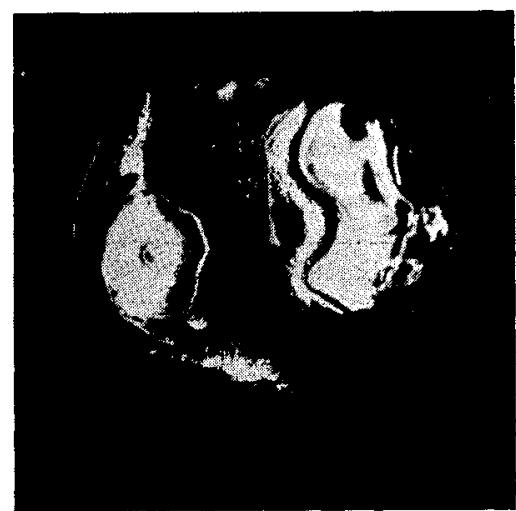

(b) $50 \% \mathrm{Mn}-50 \% \mathrm{Ba}$-Legierung

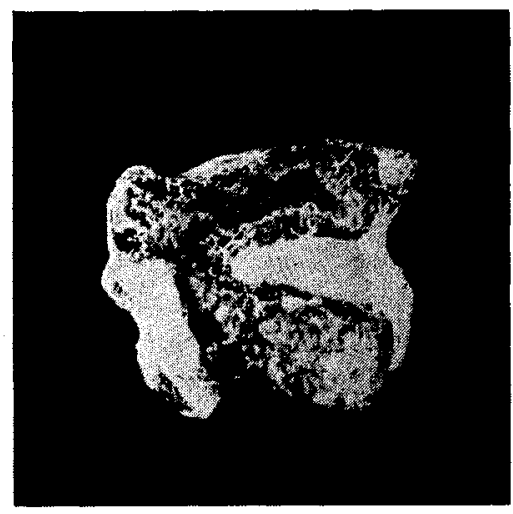

(c) $70 \% \mathrm{Mn}-30 \% \mathrm{Sr}$-Legierung

Photo.1 Aussehen der Knopf proben des Mangans mit Lithium, Barium und Strontium. 


\section{III. 組 織 の 観 察}

Photo. 1 (a)〜 (c) は，それぞれ 10\% Li，50\% Ba 拈よ び $30 \% \mathrm{Sr}$ をふくさマンガン合 金のボタン試料の外観を示 す．明らかに，いずれの合金も二つの異なつた分離相から 成り立つていることがわかる，その一つはマンガン富相 (白色)であり，他はリチウム，バリウムもしくはストロン チウム富相(暗色)である.ところで, 人はつぎの奇妙な事 実に気づくだろう．それはマンガンの比重は他の三つの金 属の比重にくらべて非常に大きいにもかかわらず, マンガ

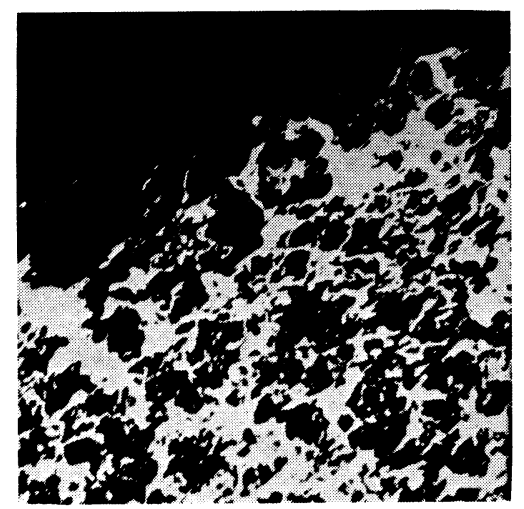

(a) $90 \% \mathrm{Mn}-10 \% \mathrm{Li}-$ Legierung

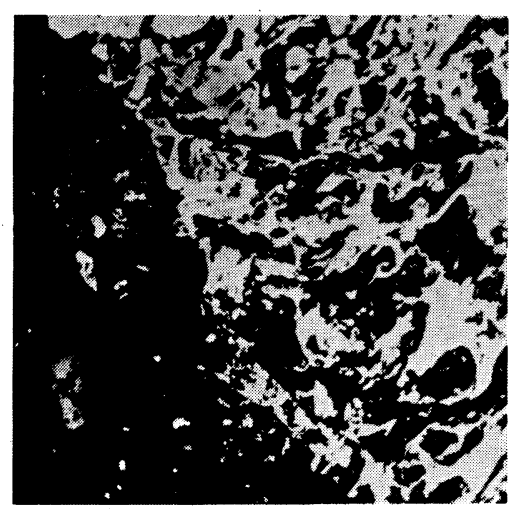

(b) $50 \% \mathrm{Mn}-50 \% \mathrm{Ba}-$ Legierung

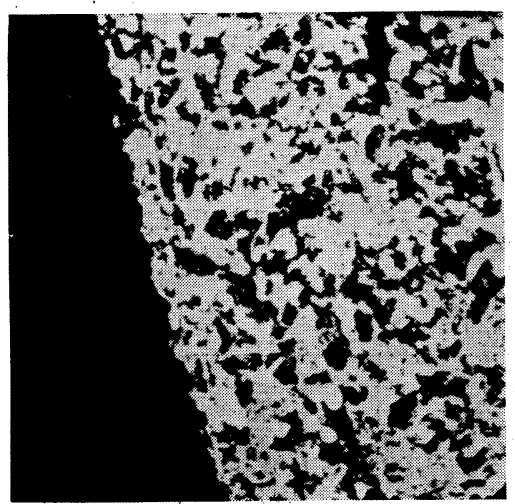

(c) $70 \% \mathrm{Mn}-30 \% \mathrm{Sr}-$ Legierung

Photo.2 Trennflächen der $z$ wei Schichten in Manganlegierungen mit Lithium, Barium und Strontium. $(\times 100)$
ン相は底部に偏析することない，むしろ大きな粒滴となつ て他の相の上に集まつてくるという事実である.これとよ く似た現象はマンガンーカルシウム合金(1)の場合にも観察 された，その原因については明らかでないが，恐らくアー クの電気的な吸引ないしは反撥作用とか, 金属融液の物理 的性質たと学ば責張力, 熱伝導などの合成効果とみなす ことができるだろう．いずれにせよ，リチウム，バリウム 特よびストロンチウムをふくむマンガン合金は，マンガ ンーカルシウム合金と同じく, 熔融状態に括いて分離し, しかも，合金成分はたがいにごくわずかしか溶け合わない ということがわからた. Photo. 2 (a)〜 (c) は, Photo.1 (a)〜 (c) に掲げた各合 金の二相境 界面の顕微 鏡組織であ る. 図に沶いて白色部がマンガン富相であり, 黒色物がリ チウム，バリウム执よびストロンチウム富相にあたる．む つとも, マンガン富相中にみられる無数の黒色物は実は金 属相ではなく大部分は孔である.なぜなら，この種の黒色 物はアーク熔解された純マンガン中にも多量に存在するか らである．これらの黒色物は再熔解を重ねることによつて 次第に消失する. Photo. 2 から，いずれの境界部にも第三 相は現われないといらこと，いいかえれば，これらの合金 系には, 中間化合物は存在しないということが結論され る.

\section{IV. 偏晶反応}

以上の組織観察から,リチウム, バリウム执よびストロ ソチゥムをふくむマンガン合金はいずれも，熔融状態にお いて二液相に分離することがわからた，それ故，これらの 合金系においては，ある特定の温度で偏晶反応がおこるは ずである。それぞれの偏晶反応温度を決定するために，一 連の熱分析を行なつた. Tabelle 2 は上記の 3 種の合金と 使用した純金属の熱分析の結果をまとめたるのである. 純 マンガンの融点は $1258^{\circ} \mathrm{C}$ と決定された. 一方, 合金の停

Tabelle 2 Ergebnisse der thermischen Analyse der verwendeten Metallen und der Legierungen des Mangans-mit $\mathrm{Ba}-$ rium, Strontium und Lithium.

\begin{tabular}{l|l}
\hline Metall od. Legierung & Haltepunkt in ${ }^{\circ} \mathrm{C}$ \\
\hline Mangan & 1258 \\
Barium & $705 \pm 5$ \\
Strontium & $760 \pm 5$ \\
Lithium & 180 \\
Mangan-50\% Barinm & 1250 und $690 \pm 5$ \\
Mangan-30\% Strontium & 1240 und $740 \pm 5$ \\
Mangan-10\% Lithium & 1253 und 180 \\
\hline
\end{tabular}

止点は，マソガンーリチウム系では $1253^{\circ} \mathrm{C}$, マンガンーハ リウム系では $1250^{\circ} \mathrm{C}$, マンガンーストロンチウム系では $1240^{\circ} \mathrm{C}$ にあらわれた。いうまでもなく，これらの停止点 が各合金系の偏晶反応温度に相当する.また，リチウムの 融点はマンガンの添加によつてほとんど影響されないに反 し, バリウム拈よびストロンチウムの融点は約 $20^{\circ} \mathrm{C}$ 低下 することがわからた。 
ボタン試料中の二つの分離相を別々に分析することによ つて, 各偏晶反応温度に扣いて平衡すべき二夜相の組成を 近似的に求めることができる. Tabelle 3 はこの目的のた めに行なつた化学分析の結果を示す. これらの分析值はい ずれも 5 箇の測定値の平均である.むろん，ボタン試料は

Tabelle 3 Ergebnisse der chemischen Analyse der entmischten Schichten in den Knopfproben des Mangans mit Barium, Strontium und Lithium.

\begin{tabular}{l|l|l|l}
\hline \hline \multirow{2}{*}{ System } & \multicolumn{2}{|c|}{ Chemische Analyse in Gew.-\% } \\
\cline { 2 - 3 } & $\begin{array}{l}\text { Manganreiche } \\
\text { Schicht }\end{array}$ & $\begin{array}{l}\text { Barium-, strontium- } \\
\text { und lithiumre1che } \\
\text { Schicht }\end{array}$ \\
\hline Mangan-Barium & $0.62 \pm 0.12 \% \mathrm{Ba}$ & $2.25 \pm 0.28 \% \mathrm{Mn}$ \\
Mangan-Strontium & $1.18 \pm 0.16 \% \mathrm{Sr}$ & $2.10 \pm 017 \% \mathrm{Mn}$ \\
Mangan-Lithium & $0.15 \pm 0.05 \% \mathrm{L1}$ & $2.51 \pm 0.24 \% \mathrm{Mn}$ \\
\hline
\end{tabular}

水冷式銅鋳型の中で急冷されながら凝固したはずであるか ら，Tabelle 3 に示した値をただちに平衡状態に拈ける值 とみなすわけにはいかない, しかし，いずれにしても，両 者の差異はごくわずかであろらと考えられる.このことに ついては後程ふたたび触れる. Tabelle 3 から各 2 元系の 偏晶反応温度近傍における 2 液相の分離領域が明らかにさ れる。すなわち，その領域はマンガンーリチウム系に拈い ては 0.15〜97.5\% Li， マンガンーバリウム系では 0.62〜 $97.8 \% \mathrm{Ba}$ ，マンガンーストロンチウム系に拈いては, 1.18 〜98\% Srに拡がつている.

\section{V. マンガンとリチウム,ハリウ ムおよびストロンチウムと の相互溶解度}

各種のボタン試料を鋼製密閉容器一場合によつてはタン グステンるつぼが併用された一につめ, 所定の各温度に長
Tabelle 4 はその化学分析の結果を示す. 表示の値はいず れも 4 箇の分析結果の平均値である. Tabelle 4 からマン ガンにたいするリチウム, バリウム拉よびストロンチウム の固溶度と温度との関係は, Abb. 2 のように示される. なお，比較のために，マンガンにたいするカルシウムの固 溶度む(1)揭げてある。図から明らかに，これらの固溶度

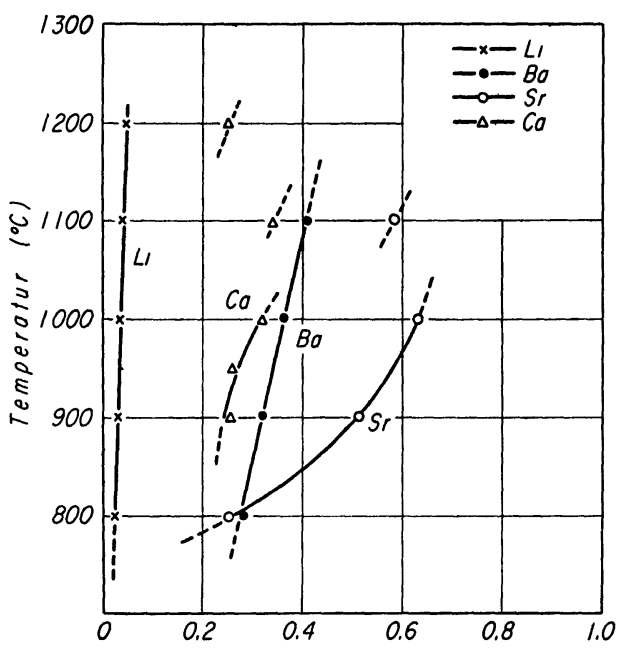

Ba. Sr, LI, Ca in Gew. (\%)

Abb.2 Löslıchkeiten von Lithium, Barıum, Strontium und Kalzium im festen Mangan.

のうち,ストロンチウムのそれが最大で，それについで カルシウム，バリウム，リチウムの順に小さくなつてい く.マンガンにたいするリチウムの固溶度はストロンチウ ムのそれにくらべて実に 10 分の 1 にもみたない。 すう一 つの特徵は、リチウムおよびバリウムの溶解度曲線はほと んど直線をなしているにたいし，ストロンチウム拈よびカ ルシウムのそれはある温度で不連続となる，この不連続性

Tabelle 4 Ergebnisse der chemischen Analyse der auf verschiedene Temperaturen erhitzten Knopfproben des Mangans mit 50\% er Barıum, Strontium und Lithıum.

\begin{tabular}{|c|c|c|c|c|c|c|}
\hline \multirow{2}{*}{ System } & \multirow{2}{*}{$\begin{array}{l}\text { Gleichgewichts- } \\
\text { temperatur in } \\
{ }^{\circ} \mathrm{C}\end{array}$} & \multirow{2}{*}{$\begin{array}{l}\text { Erhitzungszeit } \\
\text { in Std. }\end{array}$} & \multicolumn{3}{|c|}{$\begin{array}{l}\text { Barium-, Strontium-und Lithiumgehalt } \\
\text { der manganreichen Schicht in Gew.- } \%\end{array}$} & \multirow{2}{*}{$\begin{array}{l}\text { Mangangehalt der } \\
\text { barium-, strontium- } \\
\text { und lithiumreichen } \\
\text { Schicht in Gew.- \% }\end{array}$} \\
\hline & & & Barium & Strontium & Lithium & \\
\hline $\begin{array}{l}\text { Mangan } \\
\text { Barium }\end{array}$ & $\begin{array}{r}1100 \\
1000 \\
900 \\
800\end{array}$ & $\begin{array}{r}2 \\
4 \\
10 \\
20\end{array}$ & $\begin{array}{l}0.41 \\
0.36 \\
0.33 \\
0.28\end{array}$ & & & $\begin{array}{l}1.84 \\
1.43 \\
1.24 \\
0.83\end{array}$ \\
\hline $\begin{array}{c}\text { Mangan } \\
\text { Strontium }\end{array}$ & $\begin{array}{r}1100 \\
1000 \\
900 \\
800\end{array}$ & $\begin{array}{r}2 \\
4 \\
10 \\
20\end{array}$ & & $\begin{array}{l}0.58 \\
0.66 \\
0.52 \\
0.25\end{array}$ & & $\begin{array}{l}1.70 \\
1.37 \\
1.20 \\
0.75\end{array}$ \\
\hline $\begin{array}{l}\text { Mangan } \\
\text { Lithium }\end{array}$ & $\begin{array}{r}1200 \\
1100 \\
1000 \\
900 \\
800\end{array}$ & $\begin{array}{r}1 \\
2 \\
4 \\
10 \\
20\end{array}$ & & & $\begin{array}{l}0.043 \\
0.038 \\
0.035 \\
0.027 \\
0.024\end{array}$ & $\begin{array}{l}2.75 \\
2.10 \\
1.57 \\
1.21 \\
0.95\end{array}$ \\
\hline
\end{tabular}

時間加熱した後，水中に急冷した。こうして得られた内容 物について，前述と全く同じ方法で化学分析を行なつた。
は恐らくマンガンの固相変態に 起因する るのと考えられ る.一方，リチウム拈よびバリウムの溶解度にたいするマ 
ンガンの変態の影響はきわめて小さいと考えてよいだろ 5.

同様に Tabelle 4 からりチウム，バリウムおよびストロ ンチウムの各熔融金属にたいするマンガンの溶解度と温度 との関係を図示すると Abb.3のよ5になる。図からわか るよ5にいずれの熔融金属すほ活同じ程度にマンガンを溶 解し，その間に大きな差異はない。強いていえばマンガン

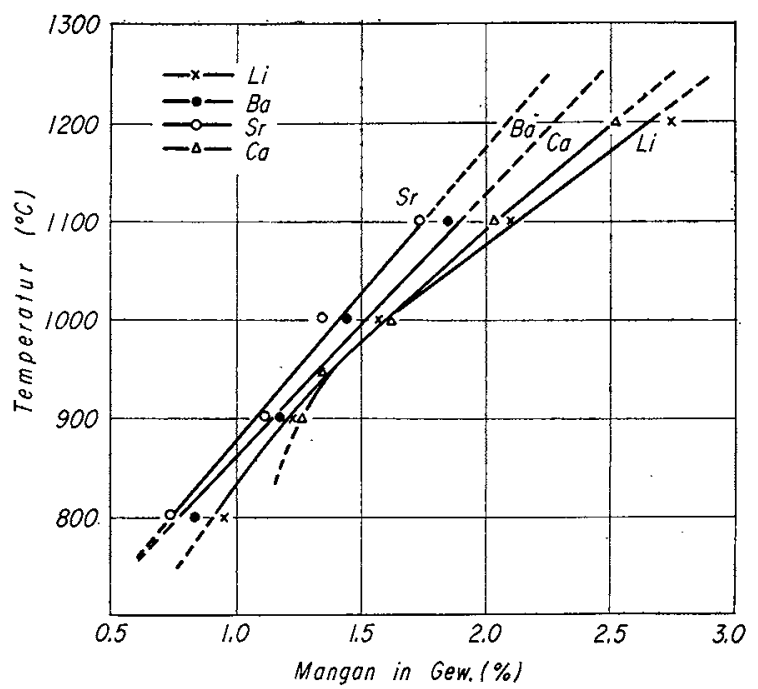

Abb.3 Löslichkeiten des Mangans in den Schmelzen von Lithium, Barium. Strontium und Kalzium.

は熔融りチウムに最す多く溶解し，ストロンチウム融液に たいしては最も少ない，今，Abb．３の各曲線をそれぞれ， の偏晶反応温度まで外插し，艺れらの温度におけるマンガ

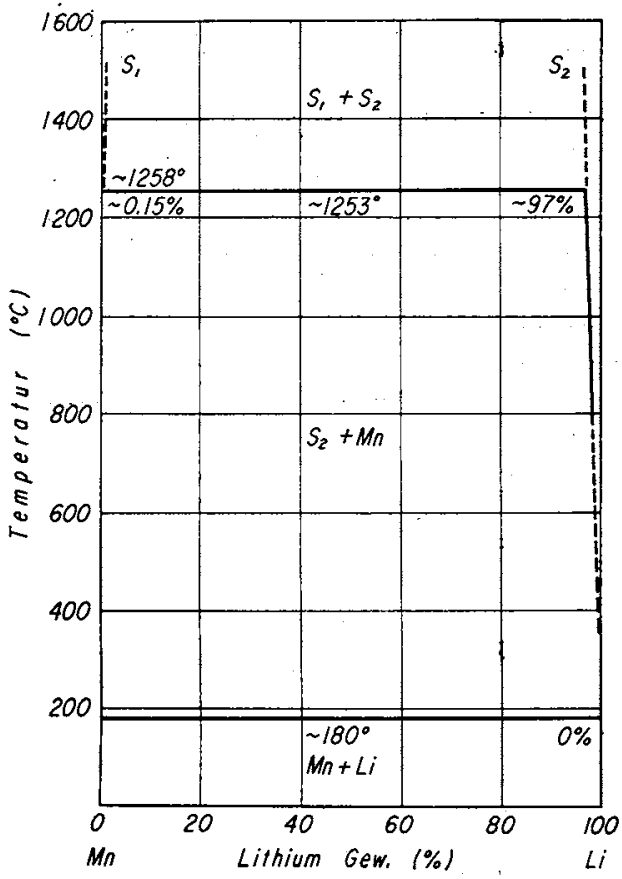

Abb.4 Zustandsdiagramm des Systems ManganLithium.
ンの溶解量を求めてみると、リチウムにたいしては約 3 \% $\mathrm{Mn}$ ，バリウムの場合には約 $2.7 \% \mathrm{Mn}$ ，ストロンチウムに たいしては約 $2.25 \% \mathrm{Mn}$ という值が得られる。これらの 値は，Tabelle 2 に揭げた值とくらべて，大きな差はない ことがかかる、したがらて，Tabelle 2 の分析值は，たと 急冷試料から得られたものであるに世上，結果的には， ば平衡值に近い值を示しているとみなすことがでさよう。

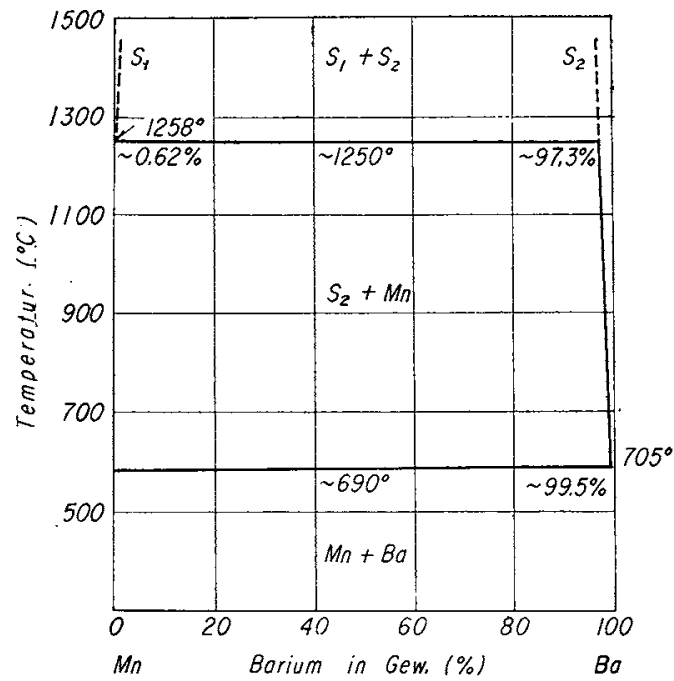

Abb. 5 Zustandsdiagramm des Systems ManganBarium.

VI. マンガンーリチウム、マンガン ハリウム, およびンカンース トロンチウム各二元系状態图

以上述べた組織観察，熱分析扣よび 化学分析の結果か ら，各二元系合 金の状態図を作製することができる。

Abb. 4 はマンガンーリチウム系，Abb. 5 はマンガンーバ

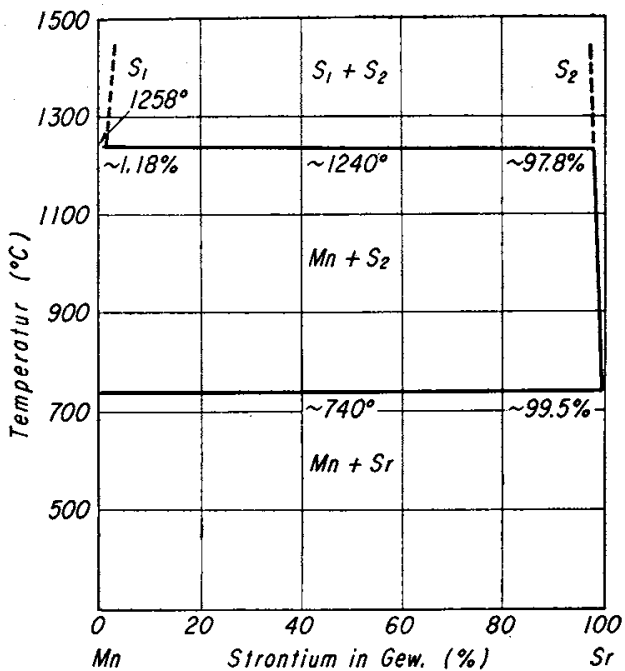

A.bb.6 Zustandsdiagramm des Systems ManganStrontium. 
リウム系および Abb. 6 はマンガンーストロンチウム系各 合金の状態図を示す。いずれの合金系にも中間化合物江存 在しない，またいずれの合金も熔融状態に招いては 2 液 相に分離する。各偏晶反応温度に和ける 2 液相の分離領域 は，マンガンーリチウム秋和いては 0.15〜97\% L1, マン ガンーバリウム系では 0.62〜97.3\% Ba，マンカンーストロ

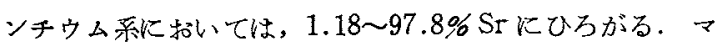
ンガンは $1000^{\circ} \mathrm{C}$ に顿いて少なくとす $0.035 \% \mathrm{L1}, 0.36 \%$ $\mathrm{Ba}$ 拈よび $0.66 \% \mathrm{Sr}$ を固容する.リチウムの融点はマン ガンの添加によつてほとんど影響されないが，バリウムお よびストロンチウムの骶点は約 $20^{\circ} \mathrm{C}$ 低下寸る.

\section{VII.むむび}

アルゴン需用気下のタングステン電極アーク熔解によつ て純䊉なマンガンーリチウム，マンガンーバリウム执よびマ ンガンーストロンチウム各合金を得ることができた 得ら れた各合金のボタン試料の組織観察，熱分析ならびに化学 分析の結果から，各合金系の状態図をそれぞれ Abb. 4, $\mathrm{Abb} .5$ 扣よびAbb.6のよ5に作製した。マンガンはりチ ウムバリウム括よびストロンチウムのいずれとも中間化
合物をつくらないばかりでなく，これらの合金は，熔融状 態において 2 液相に分離することが明らかとなつたすす

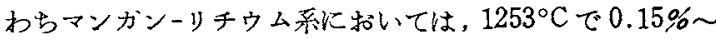
$97 \% \mathrm{Li}$ の広い組成範囲にわたつて 2 液相に分離する。同 様にマンガンーバリウム系およびマンガンーストロンチウム 系に拈ける 2 液相の分離領域は，それぞれ $1250^{\circ} \mathrm{C} て ゙ 0.62$

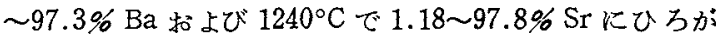
るマンガンは $1000^{\circ} \mathrm{C}$ に拀いて少なくとも0.035\%のリ チウム，0.36\%のバリウム括よび $0.66 \%$ のストロンチウ ムを固容する、一方, リチウム，バリウム扰よびストロン チウムにたいするマンガンの溶解度は，1000ㄷに和いて， それぞれ 157\%，1.43\%および $1.37 \%$ 程度である。リ ウムの融点はマンガンの添加によつてほとんど変化しない にたいし，パリウム拈よびストロンチウムのそれは，いず れも䄪 $20^{\circ} \mathrm{C}$ 低下する。

本研究の成果はつぎの諸氏の御厚意と御協力に傎うとこ ろ多大である。ここに心から感謝の意を表する，貴重な指 示と激励を与えられた W.J.Kroll 博士，数々の試料の化 学分析を担当された武山主郎講師伍よび実験結果の整理総 括に協力された大原節攐. 